\title{
Über die serologische Differenzierung von pflanzlichen ölen.
}

\author{
Von \\ Prof. Dr. Methodi Popoff und Stephan Konsuloff in Sofia.
}

[Eingegangen am 18. Juni 1916.]

Nach den grundlegenden Arbeiten von Uhlenhuth, Uhlenhuth und Weidanz, Wassermann, Nuttall u. a. über die Präcipitinreaktion und ihre praktische Anwendung ist dieselbe eine wertvolle und unentbehrliche Stütze sowobl bei der Lösung vieler wichtiger theoretischer Fragen - wie z. B. der wichtigen deszendenstheoretischen Frage über die verwandtschaftlichen Beziehungen der Lebewesen -, als auch für die forensische und nahrungshygienische Praxis geworden. Es hat sich gezeigt, daß die Präcipitinreaktion den chemischen Untersuchungsmethoden an Feinheit vielfach weit überlegen ist; so spielt sie in der Nahrungschemie als Eiweißdifferenzierungsmethode, vornehmlich für tierische Eiweißstoffe, eine nicht zu unterschätzende Rolle.

Der Versuch, präcipitierende Sera auch für pflanzliche Eiweißstoffe zu gewinnen, wurde zum ersten Male von Kowarski (1901) mit Erfolg unternommen. Die für Weizen, Hafer usw. gewonnenen Präcipitine hat er als gut brauchbares Mehldifferenzierungsmittel anwenden können. Seinen Untersuchungen folgten bald diejenige von Bertarelli, Relander, Schütze, Uhlenhuth und Jung (Präcipitine für Mohn, Kakao, Mandeln), von Jacoby (Präcipitine für Ricin, Abrin usw.) und die 1913 erschienene, besonders eingehende Arbeit von Kurt Gohlke, in welcher der Verf. durch die Präcipitinreaktion die Frage über die verwandtschaftlichen Beziehungen vieler pflanzlichen Gruppen zu lösen versucht.

Angeregt durch diese interessanten und äußerst wichtigen Befunde haben wir versucht, präcipitierende Sera für pflanzliche Öle zu gewinnen. Da die Präcipitinreaktion eine Eiweißdifferenzierungsreaktion ist, so war es von vornherein klar, daß nur solche pflanzliche Öle dazu verwendet werden können, bei welchen durch die Art der Gewinnung - Auspressen oder Extraktion unter $65^{0}$ - noch Eiweißreste erhalten bleiben. Vorderhand haben wir den Versuch gemacht, präcipitierende Sera für Erd$\mathrm{nu} \rho$ öl und Sesamöl zu gewinnen, um auf diese Weise eine handliche Methode zum Nachweise von Verfälschungen von Olivenöl mit den genannten Ölen zu finden. Im nachfolgenden berichten wir über die gewonnenen Ergebnisse. Die im Gange gewesenen Untersuchungen über Gewinnung von Präcipitinen auch für andere Ersatzöle für Olivenöl - Sonnenblumenöl, Baumwollsamenöl usw. - haben, wegen der Ungunst der ZeitverhäItnisse, nicht zu Ende geführt werden können.

Die zur Injektion dienenden Flüssigkeiten wurden folgendermaßen hergestellt: Je $5 \mathrm{~g}$ Erdnuß- oder Sesamsamen wurden gut mit Alkohol und Äther ausgezogen, getrocknet, in einem Mörser zermahlen und mit $25 \mathrm{ccm}$ physiologischer Kochsalzlösung extrahiert. Nach 2-stündigem Stehen wurde die oben stehende Flüssigkeit, je nach Bedarf, einige Male filtriert und zur Injektion verwendet. Außerdem haben wir auch Ölemulsionen zur Injektion angewendet, und zwar benutzten wir zu diesem Zwecke als am meisten eiweißhaltig den Bodensatz des betreffenden Öles. Dieser wurde im Verhältnis 1:10 mit physiologischer Kochsalzlösung gemischt und zwei Stunden geschüttelt. Mit der Injektion von Emulsionen haben wir keine guten Ergebnisse erzielen können. Deshalb haben wir uns hauptsächlich an die oben erwäbnten Samenextrakte gehalten. 
Als Versuchstiere wurden über ein Jahr alte Kaninchen benutzt. Jüngere Tiere hielten die Injektionen nicht aus. Der jedesmal frisch gewonnene Extrakt wurde intraperitoneal, in Abständen von 5-10 Tagen injiziert, - die Injektionsmenge war anfangs $5 \mathrm{ccm}$, später $10 \mathrm{ccm}$. Nach 5 bis 8 Injektionen waren die Präcipitine gut ausgebildet. Bei dem höchsten Titer wurden die Tiere, nach vorherigem 24-stündigem Hungern, entblutet und das Serum steril aufbewahrt.

Mit den auf diese Weise gewonnenen Präcipitinen wurden sowohl Samenextrakte - in Verdünnungen 1:10, 1:100, 1:1000 - wie auch Eraulsionen von den im Laboratorium durch Auspressen oder durch Extraktion mit Schwefelkohlenstoff bezw. Tetrachlorkohlenstoff gewonnenen Ölen untersucht, und zwar wurde zu je $1 \mathrm{ccm}$ des zu untersuchenden Ölextraktes $0,1 \mathrm{~cm}$ präcipitierendes Serum zugesetzt und das Resultat nach 12 Stunden abgelesen, trotzdem die Reaktion vielfach schon nach $1 / 2$ Stunde auftrat. Die Reaktion wurde als positiv angesprochen, wenn sich ein deutlicher, voluminöser Niederschlag bildete. In den unten folgenden Zusammenstellungen der Untersuchungsergebnisse bedeutet:

$$
\begin{gathered}
\text { 0 negative Reaktion, } \\
+ \text { schwach positive Reaktion, } \\
++ \text { mittelstarke Reaktion, } \\
+++ \text { starke Reaktion, } \\
++++ \text { sehr starke Reaktion. }
\end{gathered}
$$

Es wurden außerdem Ölgemische von folgender Zusammensetzung untersucht:

1. 9 Teile Olivenöl +1 Teil Sesamöl bezw. Erdnußöl; 2. 7 Teile Olivenöl +3 Teile Erdnuß- bezw. Sesamöl; 3. gleiche Teile Olivenöl und Erdnuß- bezw. Sesamöl. Als Kontrollen dienten: 1. Präcipitierendes Serum + physiologische Kochsalzlösung; 2. normales Serum mit einem der zu prüfenden Extrakte und Emulsionen.

\section{Versuche mit ErdnuBöl.}

Es wurden drei Kaninchen Serumextrakte injiziert; zwei davon starben, das überlebende zeigte Präcipitine im Blute. Zwei andere Kaninchen, denen Ölemulsionen injiziert wurden, bildeten keine Präcipitine aus. $55 \mathrm{ccm}$.

Kaninchen A. Letzte (5.) Injektion vor 6 Tagen. Injizierte Flüssigkeit

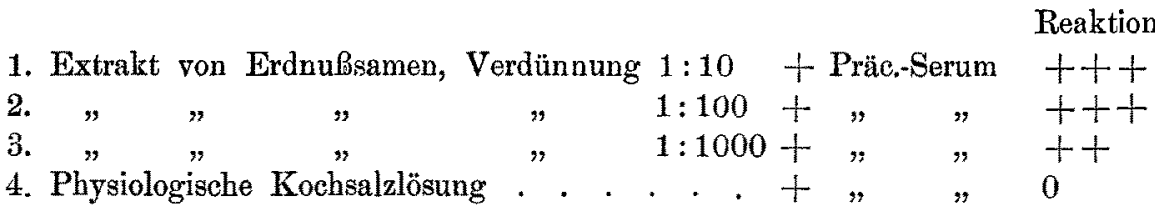

12 Tage nach der letzten Injektion zeigte das Serum desselben Kaninchens folgende Reaktionen. (Die Öle No. $5-9$ sind durch Auspressen gewonnen.) 
Reaktion

1. Extrakt von Erdnußsamen, Verdünnung 1:10 + Präc.-Serum ++

2. " " $"$

3. " " " " "

4. Physiologische Kochsalzlösung . . . . . . + " "

5. Erdnuläl-Emulsion . . . . . . . . . . + ”

6. Olivenöl-Emulsion . . . . . . . . . . + " ,

7. Olivenöl $+10^{\circ} \%$ Erdnußäl . . . . . . + " "

8. $"+30 \%$. . . . . . . + " "

9. $"+50 \%$. . . . . . . + " $"$

10. Erdnu@öl, extrahiert durch Tetrachlorkohlenstoff $+"$ "

$+1$

$+$

0

$+t+$

0

$+t+$

$++t+$

$++t$

$++t$

Die Kontrollen waren negativ.

Die präcipitierende Kraft des Serums ist im Vergleich zu der ersten Nachprüfung etwas geschwächt. Nach einer neuen Injektion wurde die präcipitierende Kraft des Serums wieder gehoben. Nach Verstreichen von einem Monat sank der Titer des Serums sehr stark, um nach 2 neuen Injektionen (injizierte Flüssigkeit insgesamt $85 \mathrm{ccm}$ ) wieder sehr hoch zu steigen, wie dies aus der nachfolgenden, 6 Tage nach der letzten Injektion vorgenommenen Nachprüfung zu ersehen ist:

Reaktion

1. Extrakt von Erdnußsamen, Verdünnung 1:10 + Präc.-Serum ++++

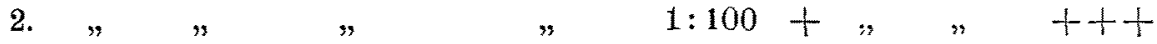

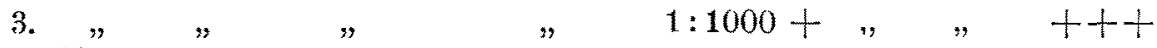

4. Olivenöl . . • • . . . . . . . . . +

5. Olivenöl $+10 \%$ Erdnußöl : . . . . . + $, ", \quad++$

6. $"+30 \%$. . . . . . . + . $",++++$

7. Olivenöl, extrahiert durch Schwefel- bezw. Tetrachlorkohlenstoff $+, \quad, \quad 0$

8. Erdnuböl, extrahiert mit Sehwefelkohlenstoff + + " $+4++$

9. " " "Tetrachlorkohlenstoff $+", "++++$ 10. 1 Olivenöl $+30^{\%} \%$ Erdnußöl, ( Tetrachlorkohlenstoff $+, ", \quad, \quad++++$ 11. extrabiert mit Schwefelkohlenstoff $+, ",++++$ 12. Erdnußöl (durch Auspressen). . . . . . + $+", \quad++++$

Die Kontrollen mit normalem Serum waren alle negativ.

\section{Versuche mit Sesamöl.}

4 Kaninchen wurde der Auszug injiziert; davon starben 3 ; das eine zeigte schon nach der 5. Injektion gut ausgebildete Präcipitine, wie dies aus der nachfolgenden, 6 Tage nach der letzten Injektion vorgenommenen Nacluprüfung zu ersehen ist: 
Reaktion

1. Sesamsamen-Extrakt, Verdünnung 1:10 . . + Präc.-Serum +++

2. " " $" 1: 100 .+4,+4$

3. " " " $" 1: 1000 .++", "$ +

4. Olivenöl . . . . . . . . . . . . + " " " " .

5. Olivenöl $+10 \%$ Sesamöl . . . . . . . . + $+"$, ++

6. $"+30 \% "$. . . . . . . . + $"$ " ++

7. $"+50 \%$, . . . . . . . . + $, ",+++$

Die Kontrollen waren alle negativ.

19 Tage nach der letzten Injektion war die präcipitierende Kraft desselben Serums sehr abgeschwächt. Sie konnte nach 2 neuen Injektionen (am 17. und 29. XI. 1914) wieder gehoben werden.

Die Öle No. 1-7 gaben dieselbe Reaktion wie oben.

8. Sesamöl, extrahiert durch Schwefelkohlenstoff + Präc.-Serum +++

9. " " " Tetrachlorkohlenstoff $+, ",+++$

10. $"$ (ausgepreßt) . . . . . . . +,$" n+++$

Die Kontrollen waren alle negativ.

Aus diesen Untersuchungsergebnissen geht hervor, daß es leicht ist, Präcipitine für pflanzliche Öle zu erhalten, welche durch Auspressen oder durch Extraktion unter $65^{\circ} \mathrm{C}$ (Erhaltung der Eiweißstoffe!) gewonnen worden sind. Diese Präzipitine können zu Differenzierungszwecken Verwendung finden. So konnten wir z. B., wie aus den vorhergehenden Tabellen zu ersehen ist, mit einem erdnußpräcipitierenden Serum die etwaigen Beimischungen von Erdnußöl in Olivenöl leicht nachweisen, desgleichen auch mit einem sesamölpräcipitierenden Serum die Beimischungen von Sesamöl in Olivenöl. Die Versuche, die Reaktion nicht nur qualitativ, sondern auch quantitativ, nach dem Volumen des gebildeten Präcipitates, auszunutzen, lieferten keine befriedigenden Ergebnisse. Da die spezifischen Präcipitine auch mit phylogenetisch nahe stehenden pflanzlichen Ölen reagieren, so erfährt dadurch naturgemäß ihre diagnostische Anwendbarkeit eine Einschränkung: sie sind mit Erfolg nur zur Differenzierung von pflanzlichen Ölen zu verwerten, die, biologisch aufgefaßt, in keiner verwandtschaftlichen Beziebung zueinander stehen.

Es wurden auch Versuche angestellt, um präcipitierende Sera für ätherische Ole, welche bei der Fälschung des Rosenöls Anwendung finden, zu gewinnen. Der Gewinnung solcher Sera stehen keine Schwierigkeiten entgegen, ob sie aber diagnostischen Wert haben werden, ist fraglich, da Eiweißbeimengungen bei den auf dem Destillationswege gewonnenen ätherischen Ölen fehlen. 